\title{
DNA Restriction and Modification in Escherichia coli: Functional Analysis of the Role of the $\operatorname{dnaC}(D)$ Gene Product
}

\author{
By JOSEF HUBÁČEK* AND MARIE WEISEROVÁ \\ Department of Molecular Biology and Genetics, Institute of Microbiology, \\ Czechoslovak Academy of Sciences, Videňská 1083, Prague 4, Czechoslovakia
}

(Received 24 July 1979; revised 21 November 1979)

\begin{abstract}
Escherichia coli strain PC-7 carries two independent temperature-sensitive mutations, one affecting the restriction and modification (R-M) phenotype and the other the DnaC(D) phenotype. The results of complementation and $\mathrm{P} 1$ transduction analysis of the mutation affecting the R-M phenotype implicate a fourth gene, designated $h s d X$, located close to the $h s d$ three-gene complex. The properties of merodiploids constructed between appropriate recipients and $\mathrm{F}^{\prime}$ elements with different mutations in $h s d S, h s d R$ and $h s d M$ genes might indicate that in strain PC-7 the temperature-sensitive products, determined by $h s d R$ and $h s d S_{\mathrm{K}}$ cistrons, are synthesized. The role of the temperature-sensitive $d n a C(D)$ gene product in the formation of the restriction endonuclease was studied and no direct relation was found between the DnaC(D) and R-M phenotypes.
\end{abstract}

\section{INTRODUCTION}

Type I restriction and modification enzymes contain two or more different subunits per enzyme in the synthesis of which the three genes $h s d S, h s d R$ and $h s d M$ are involved (Arber \& Linn, 1969; Glover \& Colson, 1969; Hubáček \& Glover, 1970; Eskin \& Linn, 1972). The mechanism of the restriction reaction is highly complex and it was thought that its complexity may be related to its involvement in other reactions such as DNA replication or recombination (Yuan et al., 1975). To explain the properties of Escherichia coli strain PC-7 dnaD mutants, which possess altered R-M phenotypes at $41^{\circ} \mathrm{C}$, the possibility was discussed that the gene product might be required not only in the initiation of DNA replication but also as a subunit of the restriction endonuclease (Paul \& Inouye, 1974).

It was therefore of interest to establish in which of the three genes the temperaturesensitive R-M mutation is located in strain PC-7. Many of the previously isolated temperaturesensitive host specificity mutants were the result of mutational events in the $h s d M$ cistron (Hubáček \& Glover, 1970; Hubáček, 1973). Most of the mutations in restriction and modification affect polypeptide subunits of the active enzymes rather than the expression of the restriction and modification genes, although trans-dominant mutants have been described by Boyer \& Roulland-Dussoix (1969).

We report here evidence that in E. coli strain PC-7 a temperature-sensitive mutation is located not in the $h s d M$ gene but in another gene which affects the R-M phenotype presumably through an altered formation of the $h s d R$ and $h s d S_{\text {к }}$ gene products. The temperature-sensitive $d n a C(D)$ gene product is not involved in the formation of multimeric restriction endonuclease.

\section{METHODS}

Bacteria. The $E$. coli strains used are described in Table 1.

Bacteriophages. $\lambda$ vir, $\lambda . h 80$, P1CMclr100, the thermoinducible mutant of P1CM variant (Rosner, 1972) and $\mathrm{f} 2$ male-specific phage were used. 


\section{Table 1. Escherichia coli strains used}

\begin{tabular}{|c|c|c|}
\hline Strain & $\begin{array}{l}\text { Host specificity } \\
\text { phenotypes }\end{array}$ & Other characteristics \\
\hline \multicolumn{3}{|l|}{$\mathrm{F}^{-}:$} \\
\hline PC-7 & $\mathrm{r}^{-} \mathrm{m}_{\mathrm{K} t \mathrm{~s}}^{+}$ & leu dra dnaC-7 thy str-r \\
\hline PC-7-11 & $\mathbf{r}^{-} \mathrm{m}_{\mathrm{K} t \mathrm{~s}}^{+}$ & leu dra dnaC-7 recA56 str-r \\
\hline RB-255 & $\mathbf{r}^{-} \mathrm{m}_{\mathrm{K}^{\mathrm{ts}}}^{+}$ & $\operatorname{ser} B$ dra dnaC-7 thy str-r \\
\hline WM301 & $\mathrm{r}_{\mathrm{K} t \mathrm{~s}}^{+} \mathrm{m}_{\mathrm{K}}^{+}$ & leu pro try arg thy met dnaC206 str-r \\
\hline C600 & $\mathbf{r}_{\mathrm{K}}^{+} \mathrm{m}_{\mathrm{K}}^{+}$ & thr leu thi str-s \\
\hline C600-5K & $\mathbf{r}_{\mathrm{K}}^{-} \mathrm{m}_{\mathrm{K}}^{+}$ & thr leu thi str-r \\
\hline C600-IV & $\mathrm{r}_{\mathrm{K}}^{-} \mathrm{m}_{\mathrm{K}}$ & leu thi str-r $(\lambda)^{+}$ \\
\hline C600-VIII & $\mathrm{r}_{\overline{\mathrm{K}}}^{-} \mathrm{m}_{\overline{\mathbf{K}}}^{-}$ & leu thi str-r $(\lambda)^{+}$ \\
\hline $\mathrm{B} 251$ & $\mathrm{r}_{\mathrm{B}}^{+} \mathrm{m}_{\mathrm{B}}^{+}$ & trp str-s \\
\hline $\mathrm{C}$ & $\mathrm{r}^{-} \mathrm{m}^{-}$ & $\operatorname{ser} B$ str-s \\
\hline $\mathrm{AB} 1157$ & $\mathbf{r}_{\mathrm{K}}^{+} \mathrm{m}_{\mathrm{K}}^{+}$ & thr leu arg pro his thi str-r \\
\hline AB2463 & $\mathbf{r}_{\mathbf{K}}^{+} \mathbf{m}_{\mathbf{K}}^{+}$ & thr leu arg pro his thi recA13 str-r \\
\hline \multicolumn{3}{|l|}{ Hfr: } \\
\hline HfrH-1 & $\mathbf{r}_{\mathrm{K}}^{+} \mathrm{m}_{\mathrm{K}}^{+}$ & thr thi str-s \\
\hline HfrH-5K & $\mathbf{r}_{\mathbf{K}}^{-} \mathrm{m}_{\mathbf{K}}^{+}$ & thi str-s ) \\
\hline HfrH-IV & $\mathrm{r}_{\mathbf{K}}^{-} \mathrm{m}_{\overline{\mathrm{K}}}^{\overline{\mathrm{C}}}$ & thi str-s \\
\hline HfrH-VIII & $\mathrm{r}_{\mathrm{K}}^{-} \mathrm{m}_{\mathbf{K}}^{-}$ & thi str-s \\
\hline HfrH-B2 & $\mathbf{r}_{B}^{-} \mathrm{m}_{\mathbf{B}}^{+}$ & thi str-s \\
\hline Hfr JC5088 & - & thr ilv recA56 spc-r str-s \\
\hline \multicolumn{3}{|l|}{ F-prime: } \\
\hline 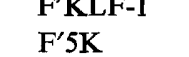 & $\begin{array}{l}\mathrm{F}^{\prime} \mathbf{r}_{\mathrm{K}}^{+} \mathrm{m}_{\mathrm{K}}^{+} / \mathrm{r}_{\mathrm{K}}^{+} \mathrm{m}_{\mathrm{K}}^{\mathrm{T}} \\
\mathrm{F}^{\prime} \mathrm{r}_{\mathrm{K}}^{-} \mathrm{m}_{\mathrm{K}}^{+} / \mathbf{r}_{\mathrm{K}}^{+} \mathrm{m}_{\mathrm{K}}^{+}\end{array}$ & $\begin{array}{l}\mathrm{F}^{\prime} t h r^{+} l e u^{+} / \mathrm{AB} 2463 \\
\mathrm{~F}^{\prime} t h r^{+} l e u^{+} / \mathrm{AB} 2463\end{array}$ \\
\hline$F^{\prime} B 2$ & $\mathrm{~F}^{\prime} \mathrm{r}_{\mathrm{B}}^{-} \mathrm{m}_{\mathrm{B}}^{+} / \mathrm{r}_{\mathrm{K}}^{+} \mathrm{m}_{\mathrm{K}}^{+}$ & $\mathrm{F}^{\prime} t h r^{+} l e u^{+} / \mathrm{AB} 2463$ \\
\hline F'IV & $\mathrm{F}^{\prime} \mathrm{r}_{\mathbf{K}}^{-} \mathrm{m}_{\mathbf{K}}^{-} / \mathrm{r}_{\mathbf{K}}^{+} \mathrm{m}_{\mathbf{K}}^{+}$ & $\mathrm{F}^{\prime} t h r^{+} l e u^{+} / \mathrm{AB} 2463$ \\
\hline$F^{\prime}$ VIII & $\mathrm{F}^{\prime} \mathrm{r}_{\mathrm{K}}^{-} \mathrm{m}_{\mathrm{K}}^{-} / \mathrm{r}_{\mathrm{K}}^{+} \mathrm{m}_{\mathrm{K}}^{+}$ & $\mathrm{F}^{\prime} t h r^{+} l e u^{+} / \mathrm{AB} 2463$ \\
\hline
\end{tabular}

Source or reference

From P. L. Carl

Thy ${ }^{+}$recombinant from JC5088 $\times$ PC-7

From R. S. Burton, Leu ${ }^{+}$ recombinant from $\mathrm{HfrH} \times \mathrm{PC}-7$

From M. Molholt

Appleyard (1954)

Hubáček (1973)

Arber \& Dussoix (1962)

Bertani \& Weigle (1953)

Howard-Flanders \& Theriot (1966)

Hubáček (1973)

$5 \mathrm{~K}$, IV or VIII mutations

transduced by $\mathrm{P} 1$ to

HfrH-1

Hubáček \& Glover (1970)

Willetts \& Clark (1969)

Diploids constructed according to Low's technique (Low, 1968)

Media. The M9 synthetic medium, L-broth (LB), L-amino acids, thiamin supplements, streptomycin concentrations, bacterial and phage buffers used were described previously (Hubáček \& Glover, 1970). The media were solidified with $1.5 \%(\mathrm{w} / \mathrm{v})$ Oxoid agar no. $3 ; 0.6 \%$ nutrient agar was used for soft agar overlays.

Preparation of $\mathrm{F}^{\prime}$ factors and methods for construction of $\mathrm{F}^{\prime}$ merodiploids. Strain $\mathrm{HfrH}-1$ was transduced with phage P1 grown on $E$. coli with appropriate mutation in the hsd gene and $\mathrm{Thr}^{+}$transductants were selected. Proximal F merodiploids were prepared according to Low (1968). HfrH strains with a host specificity phenotype $\mathrm{r}_{\mathrm{K}}^{-} \mathrm{m}_{\mathrm{K}}^{+}(5 \mathrm{~K}), \mathrm{r}_{\mathrm{B}}^{-} \mathrm{m}_{\mathrm{B}}^{+}(\mathrm{B} 2), \mathrm{r}_{\overline{\mathrm{K}}}^{-} \mathrm{m}_{\overline{\mathrm{K}}}^{-}$(IV) and $\mathrm{r}_{\mathrm{B}}^{-} \mathrm{m}_{\mathrm{K}}^{-}$(VIII) were crossed with $\mathrm{AB} 2463$ recA as recipient. From among the $\mathrm{Thr}^{+} \mathrm{Leu}^{+}$recombinants merodiploids were selected and mated with appropriate host specificity mutants. $\mathrm{Leu}^{+}$colonies on supplemented $\mathrm{M} 9$ solid medium were purified, and complementation for restriction and modification and DnaC phenotypes were tested at $30^{\circ} \mathrm{C}$ and $42{ }^{\circ} \mathrm{C}$.

Test for restriction and modification. The standard plating assays for restriction and modification were used as described previously (Hubáček \& Glover, 1970). When temperature-sensitive dnaC mutants and merodiploids were tested at $42{ }^{\circ} \mathrm{C}$, the procedures for restriction and modification assay were changed according to Paul \& Inouye (1974). In control experiments with $d n a C^{+}$cell suspensions where the standard and modified tests were compared no significant differences in efficiencies of restriction and modification were observed.

Complementation experiments for temperature sensitivity in growth. The merodiploid strains were grown overnight at $30^{\circ} \mathrm{C}$ in $\mathrm{M9}$ medium, and after subculture at the same temperature the cultures were diluted and plated at $30^{\circ} \mathrm{C}$ and at $42^{\circ} \mathrm{C}$ on minimal agar medium.

Transduction experiments. P1 lysates were prepared by thermal induction of lysogens with the thermoinducible mutant P1CMclr100 prophage. Transduction was carried out following the procedure of Rosner (1972) with a modification in the selection of transductants. Instead of keeping the plates at room temperature for $2 \mathrm{~h}$ after plating the cell suspensions on selective minimal media, the plates were placed directly 
at $35^{\circ} \mathrm{C}$ for 2 to $3 \mathrm{~d}$. This significantly lowered the frequency of P1 lysogens and about $96 \%$ of transduced colonies were thermoresistant, chloramphenicol-sensitive and did not restrict the $\lambda$ phage.

\section{RESULTS}

\section{Relationship between $D N A$ replication and $\mathrm{R}-\mathrm{M}$ phenotype}

The analysis was done with two $E$. coli dnaC $(D)$ ts mutants which also possess the temperature-sensitive R-M phenotypes. In one experiment using strain WM301 dnaCts $\mathrm{r}_{\mathrm{ts}}^{+} \mathrm{m}^{+}$we obtained stable DnaC ${ }^{+}$revertants. None of 10 colonies tested for R-M phenotype was found to be changed in the $\mathrm{r}_{\mathrm{ts}}^{+} \mathrm{m}^{+}$character. An attempt to get stable DnaC ${ }^{+}$revertants from strains PC-7 or RB255 was unsuccessful. The small colonies originally obtained at $41{ }^{\circ} \mathrm{C}$ at a frequency of about $4 \times 10^{-7}$ subsequently lost their ability to grow at higher temperature. Instead, DnaC ${ }^{+}$partial diploids of $\mathbf{r}^{-} \mathrm{m}_{\mathrm{ts}}^{+}$and $\mathbf{r}_{\mathrm{ts}}^{+} \mathrm{m}^{+}$phenotypes were prepared and their growth at higher temperature was determined. The results of these experiments are shown in Table 2 . The wild-type $d n a C^{+}$product efficiently replaced the $d n a C$ ts product of mutant PC-7-11 in the diploid $\mathrm{F}^{\prime} 5 \mathrm{~K} / \mathrm{PC}-7-11$ without alteration of the $\mathrm{r}^{-} \mathrm{m}_{\mathrm{ts}}^{+}$phenotype (experiment 2). The cell viability at $42{ }^{\circ} \mathrm{C}$ in merodiploids which express $\mathrm{K}$-specific temperature-sensitive restriction was either very low (experiment 3 ) or close to $100 \%$ (experiment 4). In experiment 5 the donor $\mathrm{HfrH}-5 \mathrm{~K}$ strain was mated with a $\mathrm{PC}-7-11 \mathrm{rec} A$ recipient and, among the rare $\mathrm{Leu}^{+}$colonies selected, true $\mathrm{F}^{-}$recombinants without activity as a genetic donor were found. The bacteria were temperature-sensitive in growth when cultivated at $42{ }^{\circ} \mathrm{C}$, and in restriction tests apparent complementation for the wild-type restriction phenotype was observed. This implies that there is no direct relationship between the DnaC and different R-M phenotypes. The bacteria which synthesize temperature-sensitive $\mathrm{K}$-specific restriction endonuclease are either $\mathrm{DnaC}^{+}$or DnaCts and the cells with the wild-type restriction phenotype have low viability at higher temperature.

Functional analysis of a temperature-sensitive host specificity mutant

Mutant PC-7 was found to be defective in restriction and modification at $41{ }^{\circ} \mathrm{C}$ and to a lesser extent also in restriction at $30^{\circ} \mathrm{C}$ (Paul \& Inouye, 1974). In our experiments the

Table 2. Restriction, modification and DnaC phenotypes in haploid and partially diploid E. coli strains

\begin{tabular}{|c|c|c|c|c|c|c|c|c|}
\hline \multirow[b]{2}{*}{$\begin{array}{c}\text { Expt } \\
\text { no. }\end{array}$} & \multirow[b]{2}{*}{ Strain* } & \multirow[b]{2}{*}{$\begin{array}{c}\text { Temperature } \\
\left({ }^{\circ} \mathrm{C}\right)\end{array}$} & \multicolumn{2}{|c|}{ Restriction $\dagger$} & \multirow[b]{2}{*}{$\underset{\mathbf{K}}{\text { Modification } \ddagger}$} & \multirow[b]{2}{*}{$\begin{array}{c}\text { Colonies } \\
42^{\circ} \mathrm{C} / 30^{\circ} \mathrm{C}\end{array}$} & \multicolumn{2}{|c|}{ Phenotype } \\
\hline & & & $\lambda \cdot \mathbf{K}$ & $\overline{\lambda . C}$ & & & R-M & DnaC \\
\hline 1 & PC-7-11 & $\begin{array}{l}30 \\
42\end{array}$ & $\begin{array}{l}1 \cdot 0 \\
1 \cdot 0\end{array}$ & $\begin{array}{l}0.6 \\
1 \cdot 0\end{array}$ & $\begin{array}{l}0.5 \\
0.02\end{array}$ & $4 \times 10^{-7}$ & $r^{-} m_{t s}^{+}$ & ts \\
\hline 2 & $\mathrm{~F}^{\prime} 5 \mathrm{~K} / \mathrm{PC}-7-11$ & $\begin{array}{l}30 \\
42\end{array}$ & $\begin{array}{l}0.6 \\
0.7\end{array}$ & $\begin{array}{l}0.9 \\
1 \cdot 0\end{array}$ & $\begin{array}{l}0 \cdot 4 \\
0 \cdot 002\end{array}$ & $1 \cdot 3$ & $\mathrm{r}^{-} \mathrm{m}_{\mathrm{ts}}^{+}$ & + \\
\hline 3 & $F^{\prime} 5 \mathrm{~K} / \mathrm{PC}-7-11$ & $\begin{array}{l}30 \\
42\end{array}$ & $\begin{array}{l}0.6 \\
0.9\end{array}$ & $\begin{array}{l}0.003 \\
0 \cdot 2\end{array}$ & $\begin{array}{l}0.7 \\
0.8\end{array}$ & $1 \times 10^{-5}$ & $\mathrm{r}_{\mathrm{ts}}^{+} \mathrm{m}^{+}$ & ts \\
\hline 4 & $\mathrm{~F}^{\prime} 5 \mathrm{~K} / \mathrm{PC}-7-11$ & $\begin{array}{l}30 \\
42\end{array}$ & $\begin{array}{l}0 \cdot 9 \\
0 \cdot 7\end{array}$ & $\begin{array}{l}0.0002 \\
0.03\end{array}$ & $\begin{array}{l}0 \cdot 7 \\
1.0\end{array}$ & 0.9 & $\mathrm{r}_{\mathrm{ts}}^{+} \mathrm{m}^{+}$ & + \\
\hline 5 & HfrH-5K/PC-7-11 & $\begin{array}{l}30 \\
42\end{array}$ & $\begin{array}{l}1.0 \\
0.9\end{array}$ & $\begin{array}{l}0.003 \\
0.007\end{array}$ & $\begin{array}{l}0.7 \\
0.7\end{array}$ & $1 \times 10^{-2}$ & $\mathbf{r}^{+} \mathbf{m}^{+}$ & ts \\
\hline
\end{tabular}

* Host specificity genotype on $\mathrm{F}^{\prime} 5 \mathrm{~K}$ is $h s d S_{\mathrm{K}}^{+} h s d R^{-} h s d M^{+}$.

$\dagger$ Where the efficiency of plating of $\lambda$ does not differ from 1.0 by more than a factor of two the difference is not regarded as significant.

$¥$ The fractions are calculated as a function of the efficiency of plating on $E$. coli $\mathrm{C}$ which is regarded as 1.0 . Where the fraction does not differ from 1.0 by more than a factor of two the difference is not regarded as significant. 
Table 3. Restriction and modification phenotypes of merodiploids

\begin{tabular}{|c|c|c|c|c|c|c|c|}
\hline \multirow{2}{*}{$\begin{array}{l}\text { Expt } \\
\text { no. }\end{array}$} & \multicolumn{2}{|c|}{ Haploid phenotype } & \multirow{2}{*}{$\begin{array}{c}\text { Temperature } \\
\left({ }^{\circ} \mathrm{C}\right)\end{array}$} & \multicolumn{2}{|c|}{$\begin{array}{l}\text { Efficiency of } \\
\text { plating } \dagger\end{array}$} & \multirow{2}{*}{$\begin{array}{c}\text { Fraction } \\
\text { K-plating } \\
\text { phaget }\end{array}$} & \multirow{2}{*}{$\begin{array}{l}\text { R-M } \\
\text { phenotype of } \\
\text { merodiploids }\end{array}$} \\
\hline & Recipient & $\mathrm{F}^{*}$ & & $\lambda . \mathrm{K}$ & $\lambda . \mathrm{C}$ & & \\
\hline 1 & $\mathrm{r}^{-} \mathrm{m}_{\mathrm{ts}}^{+}$ & - & $\begin{array}{l}30 \\
42\end{array}$ & $\begin{array}{l}0.7 \\
1.0\end{array}$ & $\begin{array}{l}1.0 \\
1.0\end{array}$ & $\begin{array}{l}0.5 \\
0.002\end{array}$ & 二 \\
\hline 2 & $\mathrm{r}^{-} \mathrm{m}_{\mathrm{ts}}^{+}$ & $\mathrm{r}_{\mathbf{K}}^{+} \mathrm{m}_{\mathrm{K}}^{+}(\mathrm{KLF} 1)$ & $\begin{array}{l}30 \\
42\end{array}$ & $\begin{array}{l}1.0 \\
\text { NT }\end{array}$ & $\begin{array}{c}0.001 \\
\text { NT }\end{array}$ & $\begin{array}{l}1 \cdot 0 \\
\mathrm{NT}\end{array}$ & $\begin{array}{c}\mathrm{r}_{\mathrm{K}}^{+} \mathrm{m}_{\mathrm{K}}^{+} \\
\mathrm{NT}\end{array}$ \\
\hline 3 & $\mathrm{r}^{-} \mathrm{m}_{\mathrm{ts}}^{+}$ & $\mathrm{r}_{\mathrm{K}}^{-} \mathrm{m}_{\mathrm{K}}^{+}(5 \mathrm{~K})$ & $\begin{array}{l}30 \\
42\end{array}$ & $\begin{array}{l}0 \cdot 8 \\
0.9\end{array}$ & $\begin{array}{l}0.004 \\
0.2\end{array}$ & $\begin{array}{l}0.9 \\
0.8\end{array}$ & $\begin{array}{l}\mathbf{r}_{\mathbf{K}}^{+} \mathrm{m}_{\mathbf{K}}^{+} \\
\mathrm{r}_{\mathbf{K}}^{ \pm} \mathrm{m}_{\mathbf{K}}^{+}\end{array}$ \\
\hline 4 & $r^{-} m_{t s}^{+}$ & $\mathrm{r}_{\mathrm{K}}^{-} \mathrm{m}_{\overline{\mathrm{K}}}^{-}(\mathrm{VIII})$ & $\begin{array}{l}30 \\
42\end{array}$ & $\begin{array}{l}0.7 \\
1.0\end{array}$ & $\begin{array}{l}0.05 \\
0.02\end{array}$ & $\begin{array}{l}0.6 \\
0.7\end{array}$ & $\begin{array}{l}\mathrm{r}_{\mathrm{K}}^{+} \mathrm{m}_{\mathrm{K}}^{+} \\
\mathrm{r}_{\mathrm{K}}^{+} \mathrm{m}_{\mathrm{K}}^{+}\end{array}$ \\
\hline 5 & $r-m_{t s}^{+}$ & $\mathrm{r}_{\mathrm{K}}^{-} \mathrm{m}_{\mathrm{K}}^{-}(\mathrm{IV})$ & $\begin{array}{l}30 \\
42\end{array}$ & $\begin{array}{l}0.8 \\
0.7\end{array}$ & $\begin{array}{l}0.06 \\
0.5\end{array}$ & $\begin{array}{l}0 \cdot 7 \\
0.002\end{array}$ & $\begin{array}{l}\mathrm{r}_{\mathrm{K}}^{+} \mathrm{m}_{\mathrm{K}}^{+} \\
\mathrm{r}_{\mathrm{K}}^{-} \mathrm{m}_{\mathrm{K}}^{-}\end{array}$ \\
\hline
\end{tabular}

NT, Not tested.

* Host specificity genotype on KLF1 is $h s d S_{\mathrm{K}}^{+} h s d R^{+} h s d M^{+}$, on $5 \mathrm{~K} h s d S_{\mathrm{K}}^{+} h s d R^{-} h s d M^{+}$, on IV $h s d S_{\mathrm{K}}^{-}$ $h s d R^{+} h s d M_{\mathrm{ts}}^{+}$and on VIII $h s d S_{\mathrm{K}}^{+} h s d R^{+} h s d M_{\mathrm{ts}}^{-}$, i.e. two mutations in the $h s d M$ gene.

$\dagger$ Where the efficiency of plating of $\lambda$ does not differ from 1.0 by more than a factor of two the difference is not regarded as significant.

$\ddagger$ The fractions are calculated as a function of the efficiency of plating on $E$. coli $\mathrm{C}$ which is regarded as 1.0. Where the fraction does not differ from 1.0 by more than a factor of two the difference is not regarded as significant.

mutation in strains PC-7 and RB255 caused complete impairment of restriction even at $30{ }^{\circ} \mathrm{C}$ (Table 3, experiment 1 ) and the R-M phenotype was designated as $\mathrm{r}^{-} \mathrm{m}_{\mathrm{ts}}^{+}$.

The individual $\mathrm{F}^{\prime}$ elements in merodiploids selected as the donors in complementation experiments carried wild-type $h s d$ genes or mutations in $h s d K, h s d R$ or $h s d M$ cistrons. The recipient was strain $\mathrm{PC}-7-11$ with the recA56 mutation and a number of stable partial diploids with different arrangements of mutant and wild-type alleles were constructed. Their ability to restrict and modify the $\lambda$ phage was determined; the results of these tests are presented in Table 3. The merodiploid constructed between $\mathrm{F}^{\prime} \mathrm{r}_{\mathrm{K}}^{+} \mathrm{m}_{\mathrm{K}}^{+}$and PC-7-11 $\mathrm{r}^{-} \mathrm{m}_{\mathrm{ts}}^{+}$ as recipient displays $\mathrm{K}$-specific restriction and modification at $30^{\circ} \mathrm{C}$ and the mutant allele which influences the $\mathrm{r}^{-}$phenotype is recessive to the wild-type allele (experiment 2 ). In experiment 3, the merodiploid with the mutation in the $h s d R$ gene on the episome expressed temperature-sensitive $\mathrm{K}$-specific restriction and normal $\mathrm{K}$-specific modification. The temperature-sensitive mutation on the resident genome is presumably in the $h s d R$ gene. In experiment 4 , interesting results were found when the $F^{\prime}$ element with a second-step mutation which impairs the $h s d M_{\mathrm{ts}}$ gene was introduced into the tested strain. The merodiploid expressed normal $\mathrm{K}$-specific restriction and modification. A possible explanation is that there are two $h s d M$ cistrons and that a hybrid protein complements the $\mathrm{m}_{\mathrm{K}}^{+}$function. If this interpretation is correct it should be possible to demonstrate complementation of normal $\mathrm{K}$-specific restriction in diploids constructed between the mutant studied and the $\mathrm{F}^{\prime}$ element with the mutation in the hsd cistron determining $\mathrm{K}$-specificity. The results of the following experiment are not compatible with this interpretation. The diploid carrying $\mathbf{r}^{-} \mathrm{m}_{\mathrm{ts}}^{+}$and type IV, i.e. $h s d S_{\mathrm{K}}^{-} h s d R^{+} h s d M_{\mathrm{ts}}^{+}$alleles, complements $\mathrm{K}$-specific temperaturesensitive restriction and displays the unchanged temperature-sensitive modification phenotype (experiment 5). It seems most likely that the mutation in the $\mathrm{r}^{-} \mathrm{m}_{\mathrm{ts}}^{+}$mutant is not located in the $h s d M$ gene.

\section{Transduction experiments and complementation analysis of transductants}

In this experiment an attempt was made to construct the reciprocal merodiploids with the $\mathrm{r}^{-} \mathrm{m}_{\mathrm{ts}}^{+}$(PC-7) allele on the $\mathrm{F}^{\prime}$ merogenote. P1 lysate was prepared on donor strain RB255 and used to transduce recipient $\mathrm{HfrH}-1$. $\mathrm{Thr}^{+}$transductants were selected and 
Table 4. Restriction and modification properties of $\mathrm{Thr}^{+}$transductants

\begin{tabular}{|c|c|c|c|c|c|c|c|}
\hline \multirow{2}{*}{$\begin{array}{l}\text { Expt } \\
\text { no.* }\end{array}$} & \multirow{2}{*}{$\begin{array}{c}\text { R-M class } \\
\text { (transductant } \\
\text { no.) }\end{array}$} & \multirow{2}{*}{$\begin{array}{c}\text { Cotrans- } \\
\text { duction } \\
\text { with } t h r^{+} \\
(\%)\end{array}$} & \multirow{2}{*}{$\begin{array}{l}\text { Tem- } \\
\text { perature } \\
\left({ }^{\circ} \mathrm{C}\right)\end{array}$} & \multicolumn{2}{|c|}{$\begin{array}{l}\text { Efficiency of } \\
\text { plating }\end{array}$} & \multirow{2}{*}{$\begin{array}{l}\text { Fraction } \\
\text { K-plating } \\
\text { phage }\end{array}$} & \multirow{2}{*}{$\begin{array}{c}\text { R-M } \\
\text { phenotype }\end{array}$} \\
\hline & & & & $\lambda . \mathbf{K}$ & $\lambda . \mathrm{C}$ & & \\
\hline \multirow[t]{3}{*}{1} & $\underset{\text { (HfrH-61) }}{\mathrm{I}}$ & 0.3 & $\begin{array}{l}30 \\
42\end{array}$ & $\begin{array}{l}0.5 \\
0.6\end{array}$ & $\begin{array}{l}0.4 \\
0.5\end{array}$ & $\begin{array}{l}0.01 \\
0.00001\end{array}$ & $\begin{array}{l}\mathrm{r}_{\mathbf{K}}^{-} \mathrm{m}_{\overline{\mathbf{K}}}^{-} \\
\mathbf{r}_{\mathbf{K}}^{-} \mathbf{m}_{\overline{\mathbf{K}}}^{-}\end{array}$ \\
\hline & $\underset{\text { (HfrH-90) }}{\text { II }}$ & $1 \cdot 1$ & $\begin{array}{l}30 \\
42\end{array}$ & $\begin{array}{l}0 \cdot 4 \\
1 \cdot 0\end{array}$ & $\begin{array}{l}0 \cdot 004 \\
0 \cdot 7\end{array}$ & $\begin{array}{l}0.8 \\
0.0001\end{array}$ & $\begin{array}{l}\mathbf{r}_{\mathbf{K}}^{+} \mathbf{m}_{\mathbf{K}}^{+} \\
\mathbf{r}_{\mathbf{K}}^{-} \mathbf{m}_{\mathbf{K}}^{\frac{1}{K}}\end{array}$ \\
\hline & $\underset{(H f r H-116)}{\operatorname{lII}}$ & $1 \cdot 5$ & $\begin{array}{l}30 \\
42\end{array}$ & $\begin{array}{l}0.9 \\
0.7\end{array}$ & $\begin{array}{l}0.0001 \\
0.006\end{array}$ & $\begin{array}{l}1 \cdot 0 \\
1 \cdot 0\end{array}$ & $\begin{array}{l}\mathrm{r}_{\mathrm{K}}^{+} \mathrm{m}_{\mathrm{K}}^{+} \\
\mathrm{r}_{\mathrm{K}}^{+} \mathrm{m}_{\mathrm{K}}^{+}\end{array}$ \\
\hline 2 & $\begin{array}{c}\text { II } \\
(5 \mathrm{~K}-102)\end{array}$ & $1 \cdot 6$ & $\begin{array}{l}30 \\
42\end{array}$ & $\begin{array}{l}1 \cdot 0 \\
1 \cdot 0\end{array}$ & $\begin{array}{l}0.02 \\
0.9\end{array}$ & $\begin{array}{l}0.5 \\
0.001\end{array}$ & $\begin{array}{l}\mathbf{r}_{\mathbf{K}}^{+} \mathrm{m}_{\mathrm{K}}^{+} \\
\mathrm{r}_{\mathbf{K}}^{-} \mathrm{m}_{\mathrm{K}}^{-}\end{array}$ \\
\hline & $\underset{(5 K-66)}{\text { III }}$ & 1.6 & $\begin{array}{l}30 \\
42\end{array}$ & $\begin{array}{l}1 \cdot 0 \\
1 \cdot 0\end{array}$ & $\begin{array}{l}0.00002 \\
0.0001\end{array}$ & $\begin{array}{l}0.8 \\
0.6\end{array}$ & $\begin{array}{l}\mathrm{r}_{\mathrm{K}}^{+} \mathrm{m}_{\mathrm{K}}^{+} \\
\mathrm{r}_{\mathrm{K}}^{+} \mathrm{m}_{\mathrm{K}}^{+}\end{array}$ \\
\hline
\end{tabular}

* P1 lysates were prepared on strains RB255 (experiment 1) and HfrH-90 (experiment 2).

purified, and tested colonies grown at $30^{\circ} \mathrm{C}$ and $42{ }^{\circ} \mathrm{C}$ in $\mathrm{M} 9$ liquid medium were streaked on LA plates and spotted with $0.01 \mathrm{ml}$ drops of $\lambda . C\left(10^{6} \mathrm{ml}^{-1}\right)$. The cultures of $\mathrm{r}^{-}$and $\mathrm{r}^{ \pm}$ phenotype at one or both temperatures of cultivation were quantitatively analysed for hostcontrolled restriction using $\lambda . \mathrm{K}, \lambda . \mathrm{B}$ and $\lambda . \mathrm{C}$, and the host specificity of the phage produced by each tested colony was scored by plating on $E$. coli $\mathrm{K}, \mathrm{B}$ and $\mathrm{C}$. The results of the transduction experiments are presented in Table 4, experiment 1 . Three classes of R-M phenotypes appeared among the $270 \mathrm{Thr}^{+}$colonies tested. Class I, isolated at a relatively low frequency $(0.3 \%)$, is similar to the $r^{-} \mathrm{m}_{\mathrm{ts}}^{+}$donor strain except that the low level of the modification at $30{ }^{\circ} \mathrm{C}$ is expressed; only about $1 \%$ of $\lambda$ in the burst is modified in comparison with about $50 \%$ of $\lambda$ modified in strains PC-7 or RB255. Class II of R-M phenotype (cotransduction frequency with $t h r$ of $1 \cdot 1 \%$ ) is exceptional in that it does not score as either donor-type or recipient-type with respect to R-M and the transductants display K-specific temperature-sensitive restriction and modification $\left(\mathrm{r}_{\mathrm{ts}}^{+} \mathrm{m}_{\mathrm{ts}}^{+}\right)$. Class III recombinants are similar to the recipient strain and express efficient restriction at $30^{\circ} \mathrm{C}$ and to a lesser extent at $42{ }^{\circ} \mathrm{C}$; phage $\lambda$ is completely modified at both temperatures $\left(\mathrm{r}_{\mathrm{ts}}^{+} \mathrm{m}^{+}\right)$.

The class II and III Thr ${ }^{+}$transductants were further analysed. $5 \mathrm{~K} \mathrm{r}_{\mathrm{K}}^{-} \mathrm{m}_{\mathrm{K}}^{+}$was transduced using phage $\mathrm{Pl}$ grown on HfrH-90. As shown in Table 4, experiment 2, the $\mathrm{r}_{\mathrm{t}}^{+} \mathrm{m}^{+}$phenotype (5K-66) appeared again with the same frequencies among $\mathrm{Thr}^{+}$transductants in addition to colonies with the donor $\mathrm{r}_{t s}^{+} \mathrm{m}_{\mathrm{ts}}^{+}$phenotype (5K-102). In a complementation analysis the merodiploid constructed between $\mathrm{F}^{\prime} \mathrm{B} 2$ and $5 \mathrm{~K}-102$ expressed temperature-sensitive $\mathrm{K}$ - and B-specific restriction; at $42{ }^{\circ} \mathrm{C}$ the $\mathrm{K}$-specific modification function was impaired and the B-specific modification was normal (Table 5, experiment 1). This result supports the idea that both the $h s d R$ and $h s d S$ products are temperature-sensitive in class II $\mathrm{r}_{\mathrm{ts}}^{+} \mathrm{m}_{\mathrm{ts}}^{+}$transductants. However, in the merodiploid constructed with $5 \mathrm{~K}-66$ as recipient normal $\mathrm{K}$ - and B-restriction and modification functions are expressed (Table 5, experiment 2). In the 5K-66 strain the $h s d R$ and $h s d S$ gene products are apparently not temperature-sensitive.

In a subsequent step phage P1 was grown on $5 \mathrm{~K}-102 \mathrm{r}_{\mathrm{ts}}^{+} \mathrm{m}_{\mathrm{ts}}^{+}$and $5 \mathrm{~K}-66 \mathrm{r}_{\mathrm{ts}}^{+} \mathrm{m}^{+}$strains and $5 \mathrm{~K}$ was transduced using these lysates. Among the $\mathrm{Thr}^{+}$transductants selected and purified using P1 lysate prepared on 5K-102 $\mathrm{r}_{\mathrm{ts}}^{+} \mathrm{m}_{\mathrm{ts}}^{+}$, both R-M phenotypes were again obtained: $5.8 \%$ were of the $\mathrm{r}_{\mathrm{ts}}^{+} \mathrm{m}_{\mathrm{ts}}^{+}$phenotype and $1.9 \%$ of the $\mathrm{r}_{\mathrm{ts}}^{+} \mathrm{m}^{+}$phenotype. On the other hand, in transduction with $\mathrm{P} 1$ grown on $5 \mathrm{~K}-66 \mathrm{r}_{\mathrm{ts}}^{+} \mathrm{m}^{+}$, among $200 \mathrm{Thr}^{+}$transduced colonies only the homogeneous class of $r_{t s}^{+} \mathrm{m}^{+}$phenotype was found, at a frequency of $10 \cdot 7 \%$. 
Table 5. Restriction and modification phenotypes of merodiploids

\begin{tabular}{|c|c|c|c|c|c|c|c|c|c|}
\hline \multirow{2}{*}{$\begin{array}{l}\text { Expt } \\
\text { no. }\end{array}$} & \multicolumn{2}{|c|}{ Haploid phenotype } & \multirow{2}{*}{$\begin{array}{c}\text { Temperature } \\
\left({ }^{\circ} \mathrm{C}\right)\end{array}$} & \multicolumn{3}{|c|}{$\begin{array}{l}\text { Efficiency of } \\
\text { plating }\end{array}$} & \multicolumn{2}{|c|}{$\begin{array}{l}\text { Fraction K- } \\
\text { or B-plating } \\
\text { phage }\end{array}$} & \multirow{2}{*}{$\begin{array}{c}\text { R-M } \\
\text { phenotype }\end{array}$} \\
\hline & Recipient & $\mathrm{F}^{*}$ & & $\lambda . \mathbf{K}$ & $\lambda . \mathrm{B}$ & $\lambda . \mathrm{C}$ & $\mathbf{K}$ & B & \\
\hline 1 & $\begin{array}{l}\mathrm{r}_{\mathbf{K}}^{+} \mathrm{m}_{\mathbf{K}}^{+}(5 \mathrm{~K}-102) \\
\mathbf{r}_{\mathbf{K}}^{-} \mathrm{m}_{\mathbf{K}}^{-}\end{array}$ & $\begin{array}{l}\mathrm{r}_{\mathbf{B}}^{-} \mathrm{m}_{\mathrm{B}}^{+}(\mathrm{B} 2) \\
\mathrm{r}_{\mathbf{B}}^{-} \mathrm{m}_{\mathrm{B}}^{+}\end{array}$ & $\begin{array}{l}30 \\
42\end{array}$ & $\begin{array}{l}0.03 \\
0.7\end{array}$ & $\begin{array}{l}0.02 \\
0.3\end{array}$ & $\begin{array}{l}0.03 \\
0.5\end{array}$ & $\begin{array}{l}0.8 \\
0.0008\end{array}$ & $\begin{array}{l}1.0 \\
0.5\end{array}$ & $\begin{array}{l}r_{\mathbf{K}}^{+} r_{\mathbf{B}}^{+} m_{\mathbf{K}}^{+} m_{\mathbf{B}}^{+} \\
\mathbf{r}_{\mathbf{K}}^{-} r_{\mathbf{B}}^{-} m_{\mathbf{K}}^{-} m_{\mathbf{B}}^{+}\end{array}$ \\
\hline 2 & $\begin{array}{l}\mathbf{r}_{\mathbf{K}}^{+} \mathbf{m}_{\mathbf{K}}^{+}(5 \mathrm{~K}-66) \\
\mathbf{r}_{\mathbf{K}}^{+} \mathrm{m}_{\mathbf{K}}^{+}\end{array}$ & $\begin{array}{l}\mathbf{r}_{\mathbf{B}}^{-} \mathbf{m}_{\mathbf{B}}^{+}(\mathbf{B} 2) \\
\mathrm{r}_{\mathrm{B}}^{-} \mathrm{m}_{\mathrm{B}}^{+}\end{array}$ & $\begin{array}{l}30 \\
42\end{array}$ & $\begin{array}{l}0.002 \\
0.005\end{array}$ & $\begin{array}{l}0.001 \\
0.001\end{array}$ & $\begin{array}{l}0.001 \\
0.004\end{array}$ & $\begin{array}{l}1 \cdot 0 \\
1 \cdot 0\end{array}$ & $\begin{array}{l}1.0 \\
1.0\end{array}$ & $\begin{array}{l}\mathbf{r}_{\mathbf{K}}^{+} \mathbf{r}_{\mathbf{B}}^{+} \mathrm{m}_{\mathbf{K}}^{+} \mathrm{m}_{\mathbf{B}}^{+} \\
\mathbf{r}_{\mathbf{K}}^{+} r_{\mathbf{B}}^{+} \mathrm{m}_{\mathbf{K}}^{+} \mathrm{m}_{\mathbf{B}}^{+}\end{array}$ \\
\hline
\end{tabular}

DISCUSSION

We have demonstrated that there is no direct relationship between the temperaturesensitive $d n a C$ gene product and temperature-sensitive restriction and modification enzymes (Table 2). Strain PC-7 carries two independent mutations, one in the dnaC gene, the other in the $h s d X$ gene which somehow regulates the function of restriction and modification enzymes. The $d n a C^{+}$and $d n a C$ ts bacteria are both of $\mathrm{r}^{-} \mathrm{m}_{\mathrm{ts}}^{+}$and $\mathrm{r}_{\mathrm{ts}}^{+} \mathrm{m}^{+}$phenotypes.

The results of complementation analysis of restriction and modification in strain PC-7 indicate that the temperature-sensitive mutation affecting the R-M phenotype is probably located in a gene other than the $h s d M$ cistron (Table 3, experiments 4 and 5). To explain the $\mathrm{r}^{-} \mathrm{m}_{\mathrm{ts}}^{+}$phenotype one could postulate (i) two mutations, one in the $h s d R$ gene resulting in an inactive form of the $h s d R$-directed subunit and the other one in $h s d S$ which is expressed in temperature-sensitive $\mathrm{K}$-specific modification, (ii) a temperature-sensitive mutation in the $h s d R$ gene, the product of which is needed for the expression of both restriction and modification, (iii) a temperature-sensitive mutation in the $h s d S$ gene with the same function as described under (ii), and (iv) mutation(s) in an additional gene which regulates the function of the $h s d R$ and $h s d S$ genes.

The first explanation is not very likely for the following reason. The merodiploid constructed between $F^{\prime} 5 \mathrm{~K}$ with an impaired $h s d R$ gene and PC-7-11 expressed temperaturesensitive K-specific restriction (Table 3, experiment 3), i.e. in strain PC-7 cultivated at $30^{\circ} \mathrm{C}$ $h s d R$-directed protein is synthesized which is inactivated by exposure to $42^{\circ} \mathrm{C}$. If the $h s d R$ product is synthesized in the analysed strain, why is the restriction phenotype not expressed at $30^{\circ} \mathrm{C}$, requiring the other gene product for expression in the $\mathrm{F}^{\prime} 5 \mathrm{~K} / \mathrm{PC}-7-11$ partial diploid? It should be emphasized that strain PC-7 was originally $\mathrm{r}^{+}$at $30^{\circ} \mathrm{C}$ and $\mathrm{r}^{ \pm}$at $41{ }^{\circ} \mathrm{C}$ (Paul \& Inouye, 1974), $\mathrm{r}^{+}$at $30^{\circ} \mathrm{C}$ and $\mathrm{r}^{-}$at $40^{\circ} \mathrm{C}$ (Wechsler, 1975) and $\mathrm{r}^{-}$at both temperatures in our experiments. As reported by Wechsler (1975), strain PC-7 with an hsd mutation in the original mutagenized background exhibited significantly less restriction at low temperature than did the strain with the $h s d$ mutation transferred to a different genetic background. In our experiments the $\mathrm{r}_{\mathrm{t} \mathrm{s}}^{+} \mathrm{m}_{\mathrm{ts}}^{+}$phenotype analogous to those observed by Paul \& Inouye (1974) and Wechsler (1975) was obtained when phage P1 grown on the $\mathrm{r}^{-} \mathrm{m}_{\mathrm{ts}}^{+}$strain was used to transduce $\mathrm{r}^{+}\left(\mathrm{HfrH} t h r^{-}\right)$or $\mathrm{r}^{-}(5 \mathrm{~K})$ recipients (Table 4$)$. The results suggest a special kind of 'extended' mutation in strain PC-7 which is separable by recombination from the temperature-sensitive mutation and is recessive to its wild-type allele (Table 3 , experiment 2). This mutation could exhibit a more general physiological effect and might alter the cells in such a way as to decrease their restricting ability.

With respect to hypotheses (ii) and (iii), our results support the idea that the $h s d R$ gene product is temperature-sensitive in PC-7. However, all hsdR mutants tested (Boyer \& Roulland-Dussoix, 1969; Arber \& Linn, 1969; Glover, 1970) are impaired in restriction only and the $h s d R$ product is not needed for modification. This is supported by our results with the merodiploid which synthesizes temperature-sensitive $\mathrm{K}$ - and B-specific $h s d R$ - 
directed subunits and displays temperature-sensitive $\mathrm{K}$-specific modification and wild-type B-specific modification (Table 5, experiment 1).

The modification phenotype could be changed by a mutation in the $h s d S$ gene which is responsible for carrying out the site recognition for restriction and modification subunits (Arber \& Linn, 1969; Glover \& Colson, 1969). If a mutation were considered to be located in that gene, the hsdS temperature-sensitive mutant protein could interact with other $h s d$ gene products and form the temperature-sensitive restriction enzyme composed of three different polypeptide subunits and the temperature-sensitive modification enzyme composed of two subunits (Hubáček \& Glover, 1970). In this case we would expect such a mutation to be recessive to the wild-type $h s d S$ allele. However, as the properties of merodiploids with $\mathrm{F}^{\prime} 5 \mathrm{~K}$ or $\mathrm{F}^{\prime} \mathrm{B} 2$ elements show (Table 3, experiment 3; Table 5, experiment 1), both the $h s d R$ and $h s d S_{\mathrm{K}}$ gene products are temperature-sensitive and their formation is unaffected by the wild-type $h s d S$ allele on $\mathrm{F}^{\prime}$ element.

The most plausible explanation (iv) takes into account an additional gene which affects the function of hsd genes and is separable by recombination with a higher frequency than could be expected from recombination between the two mutations inside the $h s d$ three-gene complex (Glover \& Colson, 1969). To explain the origin of different R-M phenotypes among $\mathrm{Thr}^{+}$transductants obtained with $\mathrm{P} 1$ phage lysate prepared on $\mathrm{r}^{-} \mathrm{m}_{\mathrm{st}}^{+}, \mathrm{r}_{\mathrm{ts}}^{+} \mathrm{m}_{\mathrm{ts}}^{+}$or $\mathrm{r}_{\mathrm{ts}}^{+} \mathrm{m}^{+}$ strains (Table 4) we postulate a temperature-sensitive mutation in a gene $(h s d X)$ which is located close to the $h s d$ three-gene complex in strain PC-7. In $\mathrm{Thr}^{+} \mathbf{r}_{\mathrm{ts}}^{+} \mathrm{m}^{+}$transductants such a mutation was eliminated during the process of DNA recombination and in the subsequent transduction experiment with $\mathrm{P} 1$ grown on this $\mathrm{R}-\mathrm{M}$ type, no further $\mathrm{r}_{\mathrm{ts}}^{+} \mathrm{m}_{\mathrm{ts}}^{+}$transductants were obtained. On the other hand, using P1 grown on $\mathrm{r}_{\mathrm{ts}}^{+} \mathrm{m}_{\mathrm{ts}}^{+}$cells both phenotypes $\left(\mathrm{r}_{\mathrm{ts}}^{+} \mathrm{m}_{\mathrm{ts}}^{+}\right.$ and $\mathrm{r}_{\mathrm{ts}}^{+} \mathrm{m}^{+}$) appear again in the subsequent transduction because the temperature-sensitive mutation in the $h s d X$ gene could be incorporated, or not, with approximately the same probability, into the recipient chromosome.

The mechanism of the $h s d X$ gene function in restriction and modification cannot be inferred directly from the complementation tests which involve such complicated multimeric proteins. The properties of merodiploids (Table 3, experiment 3; Table 5, experiment 1) might indicate that both the $h s d R$ and $h s d S_{\mathrm{K}}$ gene products are temperature-sensitive in the analysed mutant strain. Among the other possibilities we could assume that the mutation in the $h s d X$ gene affects the expression of these two host specificity genes. Alternatively, it should be considered that the mutation interferes with the assembly of the restriction and modification enzyme complexes and this could lead to a simultaneous alteration of both activities.

We thank Professor S. W. Glover for critical reading of the manuscript as well as helpful discussions.

\section{REFERENCES}

ApPleyard, R. K. (1954). Segregation of new lysogenic types during growth of doubly lysogenic strains derived from Escherichia coli $\mathrm{K}-12$. Genetics 39, 440-452.

ARBER, W. \& Dussoix, D. (1962). Host specificity of DNA produced by Escherichia coli. I. Host controlled modification of bacteriophage $\lambda$. Journal of Molecular Biology 5, 18-36.

ARBER, W. \& LINN, S. (1969). DNA modification and restriction. Annual Review of Biochemistry 38, 467- 500 .

Bertani, G. \& Weigle, J. J. (1953). Host controlled variation in bacterial viruses. Journal of Bacteriology 65, 113-121.

Boyer, H. W. \& Roulland-DussoiX, D. (1969). A complementation analysis of the restriction and modification of DNA in Escherichia coli. Journal of Molecular Biology 41, 459-472.

Eskin, B. \& LiNN, S. (1972). The deoxyribonucleic acid modification and restriction enzymes of Escherichia coli B. II. Purification, subunit structure and catalytic properties of the restriction endonuclease. Journal of Biological Chemistry 247, 6183-6191.

GLOvER, S. W. (1970). Functional analysis of hostspecificity mutants in Escherichia coli. Genetical Research 15, 237-250.

Glover, S. W. \& Colson, C. (1969). Genetics of host-controlled restriction and modification in Escherichia coli. Genetical Research 13, 227-240. 
Howard-Flanders, P. \& THeriot, L. (1966). Mutations of Escherichia coli K12 defective in DNA repair and genetic recombination. Genetics 53, 1137-1150.

HuBÁČEK, J. (1973). Functional analysis of secondstep host specificity mutations in unstable Escherichia coli heterozygotes. Journal of General Microbiology 79, 257-264.

HubÁČEK, J. \& Glover, S. W. (1970). Complementation analysis of temperature-sensitive host specificity mutations in Escherichia coli. Journal of Molecular Biology 50, 111-127.

Low, B. (1968). Formation of merodiploids in matings with a class of $\mathrm{rec}^{-}$recipient strains of Escherichia coli K12. Proceedings of the National Academy of Sciences of the United States of America 60, 160-167.

Paul, A. V. \& InOUYe, M. (1974). Temperature- sensitive modification and restriction phenotypes of an Escherichia coli dnaD mutant. Journal of Bacteriology 119, 907-912.

ROSNER, J. L. (1972). Formation, induction and curing of bacteriophage P1 lysogens. Virology 48, 679-689.

WeChSLER, J. A. (1975). Genetic and phenotypic characterization of dnaC mutations. Journal of Bacteriology 121, 594-599.

Willetts, N. S. \& ClaRK, A. J. (1969). Characteristics of some multiple recombination-deficient strains of Escherichia coli. Journal of Bacteriology 100, 231-239.

Yuan, R., Bickle, T. A., Ebbers, W. \& Brack, CH. (1975). Multiple steps in DNA recognition by restriction endonuclease from $E$. coli $\mathrm{K}$. Nature, London 256, 556-560. 